\title{
PARTY-VOTER LINKAGE IN SENEGAL \\ The rise and fall of Abdoulaye Wade and the \\ Parti Démocratique Sénégalais ${ }^{1}$
}

\begin{abstract}
Anja Osei
Dr Anja Osei is a postdoc researcher at the chair of International Relations and Conflict Management in the Department of Politics and Management, University of Konstanz, Germany

e-mail: anja.osei@uni-konstanz.de
\end{abstract}

\begin{abstract}
In March 2012 Abdoulaye Wade was defeated by Macky Sall in the hotly contested presidential elections in Senegal. This article uses the concept of party-voter linkage to examine how and why Wade and his party, the Parti Démocratique Sénégalais (PDS), lost touch with the electorate. It is argued that this failure must be viewed within the context of a complex process of social change that challenged traditional, often clientelistic, forms of linkage. As an alternative strategy, the PDS emphasised the personal charisma of its leader. Charismatic linkage, however, is naturally unstable, and the PDS began to lose public support. These findings suggest that political parties in Senegal cannot build their strategies on clientelism and charisma alone, they will have to begin to compete over issues and develop programmatic visions. If this challenge is not taken up, the long-term prospects for democratic representation and effective linkage are uncertain.
\end{abstract}

\section{INTRODUCTION}

In March 2012 the future of democracy in Senegal hung in the balance. In the run-up to the presidential election angry youth and opposition activists took to the streets, demanding the departure of the incumbent president, Abdoulaye Wade. The fact that a key role was played by young activists who came together in the Mouvement du 23 Juin (M23) is remarkable because the urban population, especially urban youth, had been a key element in Wade's rise to power in 2000.

1 I thank the anonymous reviewer for the helpful comments. 
Along with the sinking popularity of the once-adored president, the quality of democracy has also deteriorated in the past decade. What was at stake in the 2012 elections was, therefore, nothing less than the future of democracy in the country. Ultimately, Wade was defeated in the second round of elections by his former prime minister, Macky Sall. The performance of the Senegalese electoral bodies, first and foremost the Independent Electoral Commission (Commission Nationale Electorale Autonome - CENA), lent much credibility to the process. Hopefully, this peaceful transfer of power will help restore Senegal's reputation as one of the more democratic nations in Africa.

This article examines the rise and fall of Abdoulaye Wade and his Parti Démocratique Sénégalais (PDS) from the perspective of linkages - the 'interconnections between mass opinion and public decision' (Key 1961, p 409). In representative democracies the task of establishing these linkages falls to political parties as the 'central intermediate and intermediary structure between society and government' (Sartori 2005 [1976], p ix). If parties fail to provide successful linkages the bonds between public opinion and decision-making are broken. This can have grave consequences both for individual parties and politicians and for democratic representation itself (Morgan 2011, p 46; Lawson 1988, p 13).

Using the ideal types of programmatic, clientelistic, and charismatic linkage proposed by Kitschelt (2000), this article analyses how and why the linkage strategies of the PDS failed. It is argued that this failure must be viewed within the context of a complex process of social change that challenged traditional, often clientelistic, forms of party-voter linkage. Because the returns on clientelistic investments had become increasingly uncertain, the PDS emphasised the personal charisma of its leader, Abdoulaye Wade, as an alternative strategy. Charismatic linkage, however, is short lived and unstable (Weber 1978, p 246). Furthermore, the PDS completely failed to provide any programmatic linkage and did not offer any answers to Senegal's many pressing social, economic, and political problems.

These findings related to the evolution of the PDS have wider implications for Senegal's political development. In times of rapid social change parties cannot rely on clientelism and charisma alone, they have to develop more concrete visions for the future of the country and begin to compete over issues. If this challenge is not taken up the long-term prospects for democratic representation and effective linkage are uncertain.

Qualitative data for this research study were collected in interviews with national and local politicians in selected constituencies between 2006 and 2008. In addition, a small survey was conducted of voters' attitudes to political parties (100 respondents). This survey is not representative in a statistical sense; it was intended to function largely as a control and verification of the reported selfperceptions of the political parties. The article proceeds as follows: the second 
section introduces the concept of linkage and discusses it in relation to Africa; the third gives a short introduction to the political history of Senegal; the fourth and fifth sections provide a more detailed picture of the strategies employed by the PDS, and the final section discusses the findings and draws some conclusions.

\section{PARTY-VOTER LINKAGE IN AFRICA: CONCEPTS AND DEBATES Ideal types of linkage}

Political parties are 'agencies for forging links between citizens and policy makers. Their raison d'être is to create a substantive connection between rulers and ruled' (Lawson 1980, p 3). While this definition holds true for all political systems, the strategies that parties employ to create these connections vary widely. This article follows the ideal types proposed by Kitschelt (2000), who distinguishes between programmatic, clientelistic, and charismatic linkages. Programmatic political parties offer policy packages that they promise to pursue if elected (Kitschelt 2000, p 850), while clientelistic parties create bonds with their followers by offering direct, material rewards (Kitschelt 2000). Charismatic linkage relies on the personal skills of the party leader, and 'involves asymmetry between leaders and followers, but also directness and great passion' (Kitschelt 2000, p 849).

These ideal types are a good starting point for this article's research focus because they describe the central issues around which the discussion of political parties in Africa has revolved: the limited programmatic appeals of many parties, their reliance on clientelistic mobilisation and the extensive personalisation of politics in many countries (Erdmann 2004; Manning 2005). The following sections briefly discuss significant findings and debates related to each of the types.

\section{Programmatic linkage}

Many theories of voting behaviour are based on the assumption that voters make choices according to ideological or programmatic preferences (Mainwaring \& Torcal 2006, p 210). However, strong party polarisation along the classical leftright ideological continuum is found primarily in Western industrialised countries (Kitschelt, Freeze, Kolev \& Wang 2009, p 760) where the labour / capital cleavage was a driving force in party formation (Lipset \& Rokkan, 1967).

In Africa, by contrast, the working class is small and the economy is only weakly industrialised. As a consequence, the left/ right distinction does not really apply. Although African parties readily use labels such as 'liberal' and 'social democratic', elections rarely include debates about macroeconomic policy or the role of the state in the economy (Bleck \& Van de Walle 2011, p 1127). 
This ideological catch-all style reflects the conditions under which most of Africa's parties have emerged. Many of them came into being as heterogeneous coalitions of diverse interest groups during the course of the third wave of democratisation in the early 1990s. Often these groups had little in common with each other, apart from their hostility to the old regime. In addition, the dominant discourse of this period conceptualised multiparty democracy and economic liberalism as two sides of the same coin (Abrahamsen 2000, p 51). Structural adjustment generally prescribed the same economic policies in each country and precluded decisions on economic issues that should be subject to contestation in a true democracy (Mkandawire 1999, p 124). These circumstances, together with the discrediting of socialist ideas after the fall of the Soviet Union, created a situation in which political challengers had 'great difficulty in defining an alternative projet de société' (Young 1999, p 29).

Furthermore, political parties were often led by professional politicians who had once belonged to the incumbent administration or to a previous regime (Wiseman 1998, p 54). For these individuals, multiparty politics was just a way (back) to power (Aké 2000, p 133). As a result, political competition was (and still is) often reduced to leadership alternation. However, Bleck \& Van de Walle (2011, p 1139) call attention to the fact that 'African voters care deeply about many substantive issues'. There are a number of unclaimed issues that could possibly be taken up by opposition parties in the future (Bleck \& Van de Walle 2011, p 139). This indicates that there is at least the potential for an increase in ideological competition and - on the part of voters - even a demand for greater programmatic differentiation of parties. It is also worth noting that in some countries (Zambia and Ghana, for example) ideological positions seem to play at least a limited role in political competition (Cheeseman \& Hinfelaar 2009; Osei 2012).

\section{Clientelistic linkage}

Political clientelism is generally understood as the exchange of material benefits for political loyalty (Clapham 1982). Patron-client relationships are commonly viewed as a persistent feature of African politics (see, eg, Bratton \& Van de Walle 1997; Chabal \& Daloz 1999) that has continued to shape party competition even after the democratic wave. Van de Walle (2003, p 314) notes that in Africa 'parties do not really serve to aggregate interests - rather they serve a representation function in a context of clientelistic politics'.

Although clientelism can be found in almost every political system, it is much more prevalent in developing countries (Lemarchand \& Legg 1972). One explanation for this is that, with rising incomes, the utility of the material benefits traded in clientelistic relationships decreases, while the costs of clientelism may 
rise (Hicken 2011, p 299). Another explanation is suggested by Keefer (2005), who claims that there is an association between clientelism and the age of a democracy. Because competitors in young democracies are often 'less able to make credible promises to voters regarding public good provision and economic performance generally' (Keefer 2005, p 6) they rely on clientelistic strategies. Both hypotheses are compelling when one seeks to account for the difference in linkage strategies between developed and underdeveloped (or between established and more recent) democracies.

There are, however, other explanations that focus more specifically on Africa. In the context of frequently heterogenous post-colonial African countries the contribution of clientelism to national integration can be significant. Clientelism creates links between the centre of power and the periphery through large brokermediated networks that channel patronage from the highest levels of the state down to village level. Bayart (1993, p 152) describes the use of state resources to connect the post-colonial elite with local big men as the 'reciprocal assimilation of elites'. This has some major repercussions for political representation, as the relationship between rulers and the ruled becomes reliant on the links among patrons, big men, and their communities (Chabal \& Daloz 1999, p 37). Voters usually expect representatives to care for the material well-being of their communities (Chabal \& Daloz 1999, p 55). In this way, clientelism can 'reinforce loyalties to kith and kin' (Van de Walle 2003, p 311) by instrumentalising group identities in the competition for material resources.

It should be noted that despite many clichés about ethnic voting in Africa, belonging to one group or another does not, per se, structure voting choices. Rather, as Posner (2005, p 91) argues, ethnicity plays a role in voting because it is assumed to convey information about likely patterns of patronage distribution. However, recipients of patronage need not be ethnic groups: Patronage can also be distributed to regions, religious communities, or social groups such as students, the youth, or civil society employees. While the importance of clientelism in African politics is widely acknowledged, some newer studies have raised doubts about the primacy of clientelism as a means of party-voter linkage (Lindberg \& Morrison 2008; Young 2009). This suggests that we still lack comparative and well-grounded studies of the extent of the phenomenon in different countries.

\section{Charismatic linkage}

Although charisma and clientelism represent two distinct types in Kitschelt's typology, they tend to be conceptualised together in the Africanist literature. As Leonard \& Straus (2003, p 2) claim, personal rule is used as shorthand for describing patronage politics. In order to develop a clear understanding of 
charismatic linkage and to distinguish it from clientelistic linkage it is useful to recall Weber's concept of charisma. Weber (1978, p 2041) defines charisma as a 'certain quality of an individual personality by virtue of which he is considered extraordinary and treated as endowed with supernatural, superhuman, or at least specifically exceptional powers or qualities'.

The recognition of charisma by followers or disciples arises out of enthusiasm or despair and hope (Weber 1978, p 242) and is always the result of crises or complex social transformations (Weber 1978, p 244). Charisma 'repudiates the past' (Weber 1978, p 244) and is, in its purest form, hostile to formal rules. Therefore, charisma is an 'exceptional mode of linkage' (Hawkins 2003, p 1138). Thus, in party politics, the relationship between the charismatic ruler and his followers is not mediated by a strongly institutionalised party (Hawkins 2003, p 1137). The natural instability of charisma poses a major challenge to leadership succession. Consequently, charisma must be routinised, either in the form of traditionalisation - for example, as hereditary charisma - or by bureaucratisation, in which charisma is ascribed to an office rather than to a person (Weber 1978, pp 246-250).

\section{Combinations and adaptations}

In practice, linkages occur in combination (Kitschelt 2000, p 854). What determines the prevalence of one type of linkage or another is related to both the political and social environment of the party (Römmele, Farrell \& Ignazi 2005, p 19) and the interaction between parties (Morgan 2011, p 42). While each party may have an individual mix of strategies there are limits to combination. Most programmatic appeals, for example, stand in sharp contrast to the selective benefits distributed by clientelism (see Kitschelt 2000, p 855).

Thus, while programmatic and clientelistic linkages seem to be mutually exclusive, much of the Africanist literature suggests that clientelistic and charismatic appeals can coexist more easily. In patron-client networks, Van de Walle (2003, p 313) argues, very few benefits trickle down to the lower classes and most of the material gains are limited to a small elite. While Van de Walle further assumes that bonds with the wider population are established through politicised identities such as ethnicity (Van de Walle 2003, p 313), it is possible that charismatic linkage performs a similar function: charisma integrates those segments of the society that do not directly receive material benefits, especially in societies in which there has been little politicisation of identities. In the past, some African leaders, in order to compound their clientelistic strategies, have successfully invoked a symbolic repertoire featuring themselves as 'father of the nation' (Schatzberg 2001) or even as endowed with supernatural powers.

However, conflicts between clientelistic and charismatic linkages can arise 
in multiparty systems. Because charisma is difficult to sustain in a movement or party (Kitschelt 2000, p 855) personalist leaders 'tend to subjugate middle- and upper-level party entrepreneurs and are hostile to strong intermediary levels, be they clientelistic or bureaucratic' (Gordin 2002, p 531). This contradicts the logic of successful clientelistic integration, which would require binding intermediary levels - local big men, in the African context - to the party by offering them material benefits. The rotation of political personnel to prevent alternative centres of power, as described by Bratton \& Van de Walle (1997, p 86), might function perfectly in single-party states. Under conditions of multiparty democracy, however, these expelled big men can form their own political parties and contest elections. As described below, Senegal provides an example of this situation: by eliminating popular politicians who posed potential threats to his supremacy, Wade himself helped to create some of his most serious competitors in later presidential races.

Linkage strategies are also subject to change. As Morgan (2011, p 36) has noted, economic crises, social change and political reform may force parties to adapt their strategies. When they are unsuccessful at adaptation linkage will fail. Such failure can be limited to individual parties, but, in the worst-case scenario, might even lead to the collapse of the party system (Lawson \& Merkl 1988; Morgan 2011).

\section{PARTIES IN SENEGAL: A SHORT HISTORY}

Senegal achieved independence in 1960 under the country's first president, Leopold Sedar Senghor, the leader of the Union Populaire Senegalaise (UPS). A few opposition parties continued their activities after independence, but they were soon co-opted or suppressed (Diaw \& Diouf 1998, p 114), with the result that Senegal became a de facto single-party state in 1966.

The process of hegemony-building in the country is a near perfect example of what Bayart (1993, p 152) meant by the reciprocal assimilation of elites: the inclusion of both new and old elites in large patronage networks. The most important power base of the UPS was a unique, broker-mediated system of reciprocal relations between the state and important social groups; in this system a special role was played by the Islamic Sufi brotherhoods. Sufism is a mystical denomination of Islam, in which the religious leaders (marabouts) are perceived as holy men to whom their disciples (taalibe) owe their allegiance (see Copans 1980, pp 174-199). In exchange for political patronage, the marabouts urged the taalibe to support the ruling party and even gave voting instructions (ndigel) to their disciples.

There are four main Sufi brotherhoods in Senegal: the Tijaniya, the Mouridiya, the Qadiriya, and the brotherhood of the Layenne. Although the Tijaniya is the 
largest in numbers, the Mouridiya is more influential in the economic sector, specifically in peanut production and transport. All the orders are dynastically structured, tied to religious centres and led by noble families; for instance, the head (khalif) of the Mouridiya resides in the holy city of Touba. At regional and local levels, smaller marabouts are hierarchically subordinate to the khalif.

The first serious test of the hegemony of the UPS came in May 1968, when students and workers revolted against the authoritarian nature of the government (Fatton 1987, p 61; Diaw \& Diouf 1998, p 122). Supported by the French, the army and the marabouts Senghor managed to regain the upper hand, but the struggle made it clear that certain amendments would have to be made to his hegemonic style of governing. These adaptations took the form of multipartisme limité; implemented in 1976, this new system recognised three parties: a liberal, a social democratic and a communist party. The UPS, now renamed Parti Socialiste (PS), reserved the social democratic option for itself, the Parti Africain de l'Indépendance (PAI) accepted the role of the Marxist opposition and the PDS was registered as the liberal party. Using this strategy of limited and controlled liberalisation Senghor successfully appeased the opposition (see Fatton 1987, p 53).

There can be no doubt that Senghor was blessed with outstanding political intuition. Although he was charismatic and even tended towards strongman rule (Ottaway 2003, p 94), he was a 'princely' ruler (Jackson \& Rosberg 1982) who saw himself as an 'arbiter of disputes among leading politicians, lieutenants, and their factions' (Jackson \& Rosberg 1982, p 90) and who 'tolerated opposition insofar as it did not threaten his hegemony' (Fatton 1987, p 12). With regard to linkage strategies, Senghor's charisma and the clientelistic system on which state-society relations depended during this era were an effective combination.

Senghor's handpicked successor, Abdou Diouf, took over in 1981. He was a young, uncharismatic, 'three-piece-suit-wearing technocrat' (Foucher 2007a, $\mathrm{p}$ 122). In the context of a declining economy Diouf's task of upholding the dominance of the PS was a difficult one. Because the PDS had become a political force to be reckoned with Diouf decided to further fragment the opposition by removing the barriers of multipartisme limité (Diaw \& Diouf 1998, p 128; Creevey, Ngomo and Vengroff 2005, p 481). However, the economic crisis contributed to an increase in popular discontent and social unrest (Diaw \& Diouf 1998, p 133). Wade and his party benefited greatly from these developments. The PDS began to campaign using the slogan 'sopi', the Wolof word for 'change'.

In the aftermath of a series of strikes and riots during a severe school and university crisis, urban youth began to develop connections with the opposition movement (Diouf 1996, p 239). For this group, sopi 'expressed the debasement of political standards, the rise of a new, totally postcolonial generation, and a "crisis of values"' (Diouf 1996, p 244). 
The 1980s changed both the relationship between the youth population and party politics and that between religion and politics. In 1988 it seemed possible that the opposition might win the election (Villalón \& Kane 1998, p 147). However, the then-khalif of the Mourids, Abdou Lahatt Macké, still backed the regime and gave a strong ndigel in favour of Abdou Diouf. In the religious centre of Touba a large majority followed this ndigel, but in other parts of the country Mbacké's call was widely ignored (Villalón 1999, p 131). This rejection of the khalif's authority spurred a public debate over the political role of the country's religious leaders, and 1998 effectively marked the end of the offical $n$ digel.

Returning to the old strategy of co-option, in 1991 and in 1995 Diouf invited Wade to join a government of national unity. Both these governments were very short lived, because Wade felt that his participation in the administration would alienate some of his followers (Moegenburg 2002, p 149). Towards the end of the 1990s the PS's legitimacy crisis was accelerated by the party's internal power struggles. Leading members such as Djibo Ka and Moustapha Niasse left the party to found their own parties. In the first round of the 2000 presidential elections Diouf held a lead over Wade, but in the run-off the entire opposition including the third-place candidate, Niasse - united behind the PDS candidate. In the subsequent parliamentary elections the PDS-led Sopi-Coalition won a landslide victory; the PS did not win a single department.

The initial enthusiasm over the victory of sopi soon died down, and the years following the 2000 election were marked by a steady deterioration in the political climate. Power became strongly centralised in the hands of the president, the opposition remained ineffective and engaged in in-fighting and Wade won the first round of the 2007 presidential elections with ease. Although the electoral process was deemed by international observers to have been largely free and fair the opposition accused the president of electoral fraud and boycotted the subsequent parliamentary elections.

The opposition remained fragmented, but the ruling party was also beginning to show the first symptoms of decline. Wade's attempt to make his son, Karim, the party's next presidential candidate was resented by both the party and the wider populace. As a result, Wade decided not only to stand for a third term but also to introduce a constitutional amendment that would ensure his re-election. Although the draft amendment had to be withdrawn after mass demonstrations in June 2011, the legality of Wade's candidacy remained the subject of controversy, as the Senegalese Constitution limits the president to two terms.

The following section will examine in greater detail the linkage strategies the PDS employed, in an attempt to explain how the party lost touch with the electorate. 


\section{LINKAGE STRATEGIES OF THE PDS}

\section{Programmatic linkage}

Political parties were never officially outlawed in Senegal, consequently Wade was able to form the PDS as a legal opposition party in 1974. The original ideological conception of the party was that of socialisme travailliste, which was rooted in the work ethic of the Mourid brotherhood and promoted economic development on the basis of agricultural production (see Desouches 1983, pp 52-54). However, under the tripartisme scheme there was no place for such a party and a departure from the prescribed ideological orientation was not permitted (see also Fatton 1987, p 7). Hence, the PDS found itself labelled the official liberal party. At first, leading party cadres (including Wade himself) rejected liberalism for fear of being identified with conservative, right-wing policies (Sadji 2006, pp $290 \mathrm{ff}$ ).

In later years the PDS fully embraced a liberal ideology, at least rhetorically. The party joined the Liberal International in 1980 and established international contacts - with the German Liberal Party, for example (Sadji 2006, p 289). This international recognition of the PDS and, specifically, of Aboulaye Wade (sometimes referred to as the 'father of African liberalism'), may have contributed to the growing self-identification of the party with liberalism. As late as 1981, however, when the ideological barriers of multipartism limité were lifted, the leadership seriously considered returning to the party's original conception of socialism travailliste by removing all references to liberalism from the party statutes (Sadji 2006, p 291). Even today, Article 1 of the party statutes identifies the abolition of all forms of inequality, exploitation and alienation as the main objectives of the party (PDS nd).

Party officials interviewed during fieldwork were equally ambiguous on this point. On the one hand, most officials did not fail to insist on their liberal orientation, stressing values such as individual liberty, freedom of expression and private entrepreneurship. On the other, social values such as solidarity and social unity were also mentioned. Using the argument that individual freedom requires a certain degree of social justice the PDS thus represented itself as both a liberal and a social party (Thiare interview 2007). In general, the party seemed to have a very low ideological profile and referred only vaguely to programmatic issues.

In practice, many PDS policies have violated core values of liberalism. Allegations of corruption have been widespread and Wade's approval of expensive prestige projects like the Monument de la Renaissance in Dakar has attracted criticism (DeJong \& Foucher 2010). Critics have also complained about the harassment of opposition figures and of increasing threats to the freedom of the press (Havard 2004, pp 34-36). It is telling that it was under an administration that called itself liberal that Senegal lost its status as a 'free' country in the 2008 Freedom House report. 


\section{Clientelism}

Clientelism has always played a crucial role in Senegalese politics. Beck (2008, p 3) holds that 'clientelism remains the basis for political mobilization and accountability', a view that is shared by many other writers (Gellar 2005, p 158; Dahou \& Foucher 2009, p 26). While the overall importance of clientelism is beyond dispute, it is useful to trace the changes and adaptations in this linkage type over time.

The delicate relationship between religion and state power in Senegal has been explored in many classical studies (Coulon 1981; Copans 1980 and others). As far back as colonial times the marabouts had served as intermediaries between the rural population and the state. Senghor, although he was himself a Catholic, viewed the religious leaders as intermediaries "between the "center" of power and the "taalibe-periphery"' (Fatton 1987). The material benefits obtained by the marabouts for their cooperation included land, financial benefits (for example, special credit lines) and, in the case of the Mouridiya, the complete autonomy of the holy city of Touba from the state.

In return, the marabouts ordered their disciples to support the ruling party. Because of the hierarchical structure of the brotherhoods, the sacred aura of the marabouts and the resulting compliance of the taalibe with voting instructions the Senegalese variant of state-society relations was an efficient method of stabilising power (Cruise O'Brien 2003, p 193; Fatton 1987, p 97) and also helped to bridge ethnic differences by offering an alternative identification (Cruise O'Brien 1998).

In the 1980s the decline of state resources began to jeopardise the distributive capacity of the government, thus weakening the patronage link between it and the religious authorities. In addition, the brotherhoods were forced to adapt to a long-term process of social transformation marked by urbanisation and migration, democratisation and the decline of the peanut sector (Villalón \& Kane 1998; Villalón 1999). The 'Marabouts de l'arachide' described in Jean Copans's (1980) book have become 'Mourides des champs, mourides des villes, mourides du téléphone portable et de l'internet [Mourides of the fields, mourides of the towns, mourides of the portable telephone and of the internet]' (Copans 2000). These changes are described succinctly by Cruise O'Brien (2003, p 208):

Mouridism is changing, becoming more associational and in its own way more democratic. At the same time the brotherhood is beginning to blur around the edges, notably in the towns where being a Mouride can be an aspect of one's identity, not as in the village necessarily the major element of self-definition. 
Movements such as the Moustarchidina and the Hizbut Tarqiyyah sought to modernise the brotherhoods from within (Villalón 2004, p 64); the Moustarchidina even began to align with the opposition.

In this changing environment the continued support of the khalif of Touba for the PS regime in 1988 hurt the credibility of the Mouridiya to some extent (Cruise O'Brien 2003, p 204). The khalif's silence in subsequent elections was a logical consequence that restored his moral authority. However, the end of the official ndigel did not lead to the religious authorities' complete withdrawal from politics. Rather, it resulted in a fragmentation of the ndigel that gave smaller marabouts the opportunity to decide their own positions and to negotiate the price for their support (Audrain 2004, p 104). This development has increased the potential instability in the relationship between politics and religion and has allowed new alliances to form. In 2000 many smaller marabouts gave their own voting instructions (Villalón 2004, p 66). However, the ndigel of Cheikh Tidiane Sy (of the powerful Sy family) in favour of Diouf was ignored and Modou Kara Mbacké was booed when he set out to give a voting instruction for Diouf in 1999 (Audrain 2004, p 100).

Wade, himself a disciple of the Mouride brotherhood, tried to rebuild old clientelistic alliances in a different fashion (Dahou \& Foucher 2009, p 25). Just a few days after his election in 2000 he went to Touba to kneel before the khalif. Critics have bemoaned Wade's lopsided preference for the Mouridiya as a departure from the legacy of Senghor and Diouf, who attempted to accommodate all religious groups on equal terms (Mbow 2008, p 161; Dahou \& Foucher 2009, p 25).

Mbacké, the department in which Touba is located, became one of Wade's electoral strongholds, even though the PDS had no effectively organised party branch there. The party's success in this department relied on a combination of favours to individual marabouts and infrastructure projects in Touba. In 2007, shortly before the presidential election, the khalif even gave a sort of indirect ndigel, in which he declared openly that Wade, if re-elected, would complete the modernisation of the city's infrastructure. In addition, the PDS tried to buy off many of the smaller marabouts who had previously supported the PS. One of these leaders reported that he had been offered a car, a house in Dakar, and a sizeable amount of cash to cross over to the ruling party (Fall interview 2007).

This lavishing of expensive favours on religious authorities is not restricted to Touba and its surroundings, nor is it exclusively practised by the PDS; clientelism is still a commonly used linkage strategy all over the country (Sy Diallo interview 2007; Kane interview 2007; Fall interview 2007). It goes without saying that these practices pose serious challenges to many of the small and under-funded opposition parties that cannot compete with such generous spending. Thus, although maraboutic support is, in principle, negotiable, only a few marabouts 
openly align with the opposition. As one Sy Diallo (intervew 2007) stated, 'les marabouts jouent le jeu du pouvoir [the marabouts play the power game]'.

It is not easy to determine to what extent and in which direction voting behaviour is still influenced by the marabouts. Some results of an Afrobarometer survey $^{2}$ are very interesting in this regard. A total of $77.7 \%$ of Afrobarometer respondents stated that religious authorities had no influence on their political decisions; only $14.6 \%$ reported being very influenced. ${ }^{3}$ Not surprisingly, Mbacké is the only department in which a majority $(60.7 \%)$ of respondents said they were very influenced. In contrast, $90 \%$ of the respondents in Thiès and $84.4 \%$ in Dakar said that they did not listen at all to the marabouts when making their political decisions.

We must bear in mind that there is a strong trend in public opinion to reject the direct influence of the marabouts in the political realm. Therefore, we cannot exclude the possibility of interview effects and self-censorship in the survey responses. On the other hand, the figures are so high that they raise doubts about the ability of the religious authorities to control the votes of their communities. If these doubts are valid it would be dangerous for any party to rely on clientelistic relations with the marabouts.

This conclusion was borne out again in 2012. Unsurprisingly, Wade began his campaign tour in Touba but, given the uncertainty about the outcome of the elections, most of the religious authorities shied away from making any definite statements. One of the few to support Wade openly in the first round was Cheikh Béthiou Thioune, who gave the number of his taalibe as two million; this could be an extreme overstatement. The pro-Wade $n$ digels increased ahead of the second round: Modou Kara Mbacke, Cheikh Tidiane Sy of the Moustarchidina, Cheikh Ndiguel Fall and Serigne Kosso Mbacke also announced their support of Wade. The fact that Wade lost indicates that ndigels are no longer enough to decide elections in Senegal.

Naturally, clientelistic benefits are not directed only at religious communities. As Dahou \& Foucher (2009) argue, the improvement of the financial capacity of the Senegalese state led to an expansion of the civil service and an increase in the number of assembly members and ministers. These measures can be seen as attempts to satisfy the patronage demands that arose from within the PDS and its allies. The difficulty of managing intra-coalition patronage was one of the causes of the extreme personalisation and centralisation of the party. As described in the next section, however, the cure was worse than the disease; in the long run

2 Afrobarometer measures the social, political, and economic atmosphere in Africa. See www. afrobarometer.org

3 Afrobarometer question Q88 for Senegal asks respondents to what extent their voting decisions are influenced by other people. Q88A refers to religious authorities. 
it was precisely this over-centralisation that presented the greatest obstacle to effective patronage management. In addition to patronising the political class, Wade channelled group patronage to urban sectors (Dahou \& Foucher 2009, p 24). This strategy is especially noteworthy for its limited success: in the 2009 local elections the PDS actually achieved its best results in rural areas, not in the densely populated cities. This trend continued in 2012, when Wade's lowest levels of support came from the densely populated urban centres of Dakar and Thiès. ${ }^{4}$

From the perspective of clientelistic linkage a general conclusion can be drawn: although clientelism is still an important strategy for political parties these exchange-based relations produce increasingly uncertain returns on investment. While parties and candidates are still competing for the support of the marabouts clientelist relations between the state and the Sufi orders have undergone a profound change. On the one hand, the marabouts are no longer exclusively tied to one particular party but can shift parties and negotiate their affiliations; on the other, the disciples' strict obedience to voting instructions is no longer guaranteed and the authority of the marabouts in the political sphere is increasingly coming under scrutiny. Religious leaders distancing themselves from the state in times of uncertainty or crisis is, in itself, not a completely new phenomenon (see Fatton 1987, p 99), but in the context of a multiparty system with a large number of competing parties this adds to a general uncertainty over the return on clientelistic investments.

\section{Charisma}

Wade tends to be portrayed by friends and enemies alike as an extraordinary character. Lamine Faye $(2005, \mathrm{p} 9)$ regards him as one of Africa's most charismatic and popular leaders, holding almost mythical status in the minds of the Senegalese people. The journalist Abdou Latif Coulibaly, one of Wade's most outspoken critics and author of the controversial book, Wade, un opposant au pouvoir (2003), depicts the president as an enigmatic character: eccentric, opinionated and unconventional. Amath Dansokho, leader of the small Parti de l'Indépendence et du Travail (PIT), once referred to Wade as a car with no brakes (cited in Coulibaly 2003, p 115) and Mbow (2007, p 158) notes that 'Wade does not govern: he reigns.'

However, Wade's image is not that of a brutal dictator. Nicknamed 'le pape $d u$ sopi [the pope of sopi]' or 'le vieux [the old one]', he has often tried to give the impression that he is down-to-earth and close to the people. One anecdote related in Coulibaly's book is significant in this regard. The president was travelling

4 Regional results are available at: africanelections.tripod.com/sn_detail.html - 2012_Presidential_ Election_\%28First_Round\%29 
on the road from Dakar to Thiès, with his security force driving in front of him. Suddenly, the security officers realised the president's car had disappeared. When they went back, they found Wade on the roadside, surrounded by cheering market women, having stopped to buy mangos. Such stories fed the myth that Wade was still 'one of the people' (see also Cruise O'Brien 1998, p 46). Foucher's (2007a) observations on Wade's campaign style in 2000 illustrate this point further. Because the PDS at that time could not afford to pay for praise singers or other elements that had traditionally been used in the PS's political campaigns, the party began to organise caravans of cars that came to be known as the 'blue marches' (marches bleues). Wade broke with Diouf's political style by speaking in Wolof instead of in French, by wearing traditional boubous rather than Western-style suits and by playing Senegalese pop music and reggae at his marches (Foucher 2007a, p 124).

There can be no doubt that Wade was the dominant figure in the PDS, a party with a surprisingly underdeveloped formal organisation. ${ }^{5}$ Party offices were not set up in every region in the country and important activities (such as the annual sale of party membership cards) were not carried out regularly (Dibi Diallo interview 2007). The staffing level was remarkably thin and, in some places, the PDS was virtually absent. Wade himself was the president of the republic and general secretary of the party at the same time, managing to unite all the executive organs of the party under his tight control. In practice, the meetings of the highest executive organs of the party took place only at long intervals and were summoned exclusively by Wade. As one leading party official admitted frankly, 'There is no number two. We are all variables; Wade is the only constant' (Ba interview 2006). During elections the party has relied more heavily on its leader's popularity than on grassroots mobilisation (Ba interview 2006).

The organisational weakness of the ruling party is no secret in Senegal, and even high party cadres have admitted these problems. ${ }^{6}$ In an interview with the journal Wal Fadjiri [11 February 2008], El Hadji Ndiaye, a former ally of Wade, claimed that the PDS was not really a political party; it resembled, rather, a 'tribe of which Abdoulaye Wade is the chief': '... le PDS fonctionne comme une tribu dont Abdoulaye Wade est le chef [...] Le PDS, sous sa forme actuelle, n'est pas un parti politique.'

To a certain extent these organisational problems were caused by a phenomenon that is referred to in Senegal as political nomadism (transhumance politique). The PDS transformed rapidly from a relatively small and urban-based opposition

5 In comparison to the PS, and even the small AFP, the PDS's organisation is weak and unprofessional. For more detail, see Osei 2012.

6 In an interview with Le Soleil, Babacar Gaye, Wade's Cabinet director, stated, 'Nous sommes un parti fort, massif, mais dont l'organization laisse à désirer [We are a strong party, massive, but our organisation leaves a lot to be desired].' (Le Soleil, 15 October 2008). 
party into a large national movement, but it was unable to integrate newcomers sufficiently. Overall, the party made little effort to build up an institutionalised party apparatus with functioning branches and clear - or at least calculable - rules for career advancement. As a result, conflicts arose between the old guard, who had followed Wade on his long road to power, and an ambitious new generation (Ba interview 2006).

At first, Wade's strong leadership and the centralisation of the party was attributed to the need to hold the ranks together. In the longer run, however, this strategy contributed to the weakening of the PDS because it contradicted the imperatives of coalition-building through clientelism: instead of integrating big men into the party Wade began to eliminate all possible competitors for party leadership, thereby eroding the party's electoral base.

The examples of Idrissa Seck and Macky Sall - Wade's 'political sons', as they were often called in the Senegalese press - are instructive in this regard. Seck, a former prime minister and mayor of Thiès, was viewed as Wade's most likely successor until he was arrested and charged with treason in 2005. The charges were later dropped and Seck went on to found his own party, Rewmi. In 2007 he contested the presidential elections and was runner up to Wade. Seck's rise not only produced a new political competitor, it totally paralysed the PDS in its former stronghold of Thiès, where two-thirds of party members crossed over to Rewmi (Faye interview 2007). Later, however, Seck lost some popularity because of his various attempts to rejoin the PDS.

After Seck, Macky Sall held the post of prime minister but fell out of favour with the president when he summoned Abdoulaye Wade's son, Karim, to a hearing in the National Assembly in connection with financial irregularities in the Agency for the Organization of the Islamic Conference, which Karim directed (Mbow 2008, p165).

When Sall lost his position in the administration he founded his own party, the Alliance pour la République/Yaakaar (APR). Like Seck, Sall had a significant local following in his home town of Fatick; in contrast to his predecessor as prime minister, however, Sall was able to wage a strong electoral campaign throughout the country and ultimately won the presidency in 2012. These two examples demonstrate that Wade's electoral defeat was, to a certain extent, home-made: He removed from the party two big men with considerable local followings, both of whom were able to present a greater electoral challenge to him than the rest of the opposition.

The exclusion of these two talented politicians from the PDS must also be seen in the context of Wade's attempt to create a dynasty. Though he officially denied them, rumours that started in 2006 that Karim would succeed his ageing father spread widely. However, this strategy proved to be disastrous because of 
Karim's unpopularity among the Senegalese people. When he ran for the post of mayor of Dakar in 2009 his campaign was a miserable failure. Faced with this widespread popular disapproval of his son, Wade took the controversial decision to stand for a third term himself, despite his initial promise to step down after two terms in office. There was simply no alternative candidate within his party; the rest is history.

\section{A GLIMPSE OF VOTERS' ATTITUDES}

Thus far, this article has examined party-voter linkage from a top-down perspective. Can anything be said about voters' attitudes to political parties in Senegal, especially with regard to the PDS? Unfortunately, there are very few empirical data available to answer this question. However, the results of a survey that complemented the qualitative field work on which this article is based can offer some insight. Survey respondents were asked to assess to what degree Senegalese parties possess certain characteristics derived from the parties' selfperceptions. Although the PS is not the subject of the article, a comparison between the two parties (the PS and the PDS) offers some interesting results, displayed in Figures 1 and 2.

Figure 1

Voters' attitudes to the PDS

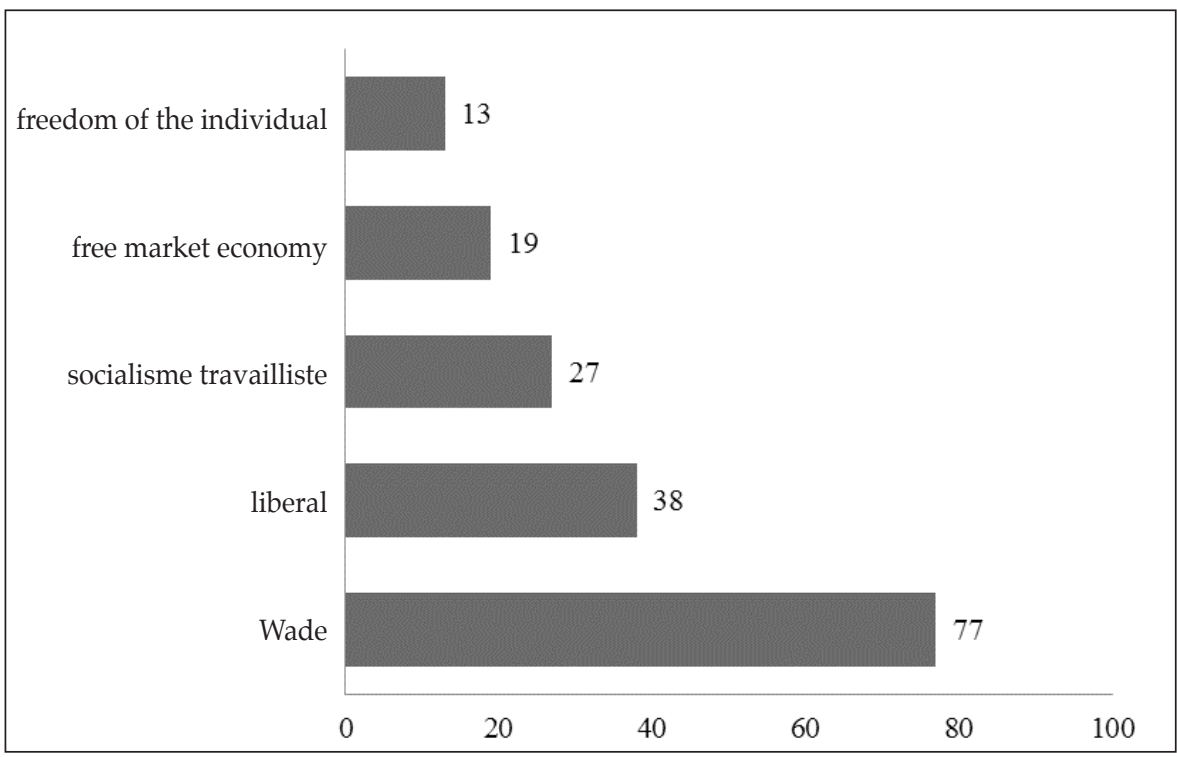

Source: Compiled by the author 
Figure 2

Voters' attitudes to the PS

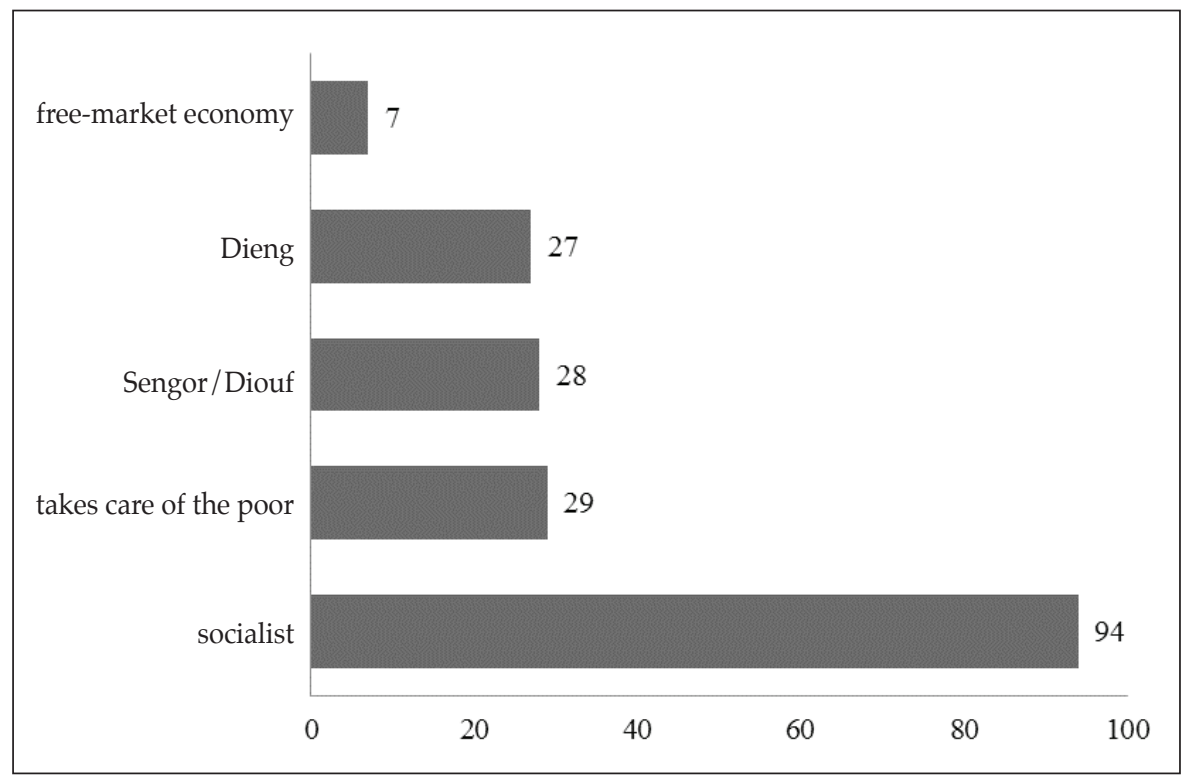

Source: Compiled by the author

Only a minority of respondents identified the PDS with the ideology of liberalism or liberal core values, such as the free-market economy or individual freedom. A total of $77 \%$ s indicated that Wade was their sole association with the party. In the case of the PS, by contrast, voters were able to identify at least some of the party's core characteristics. This is not to say that the PS's political programme is of greater substance, or that the party has a more clearly defined political vision. The words 'socialist' and 'liberal' are broad labels that are not necessarily reflected in government policies. However, these results illustrate that the PS has an identity as a political party that goes beyond a specific party leader.

Table 1

Trust in political institutions

\begin{tabular}{|l|c|c|}
\hline & $\mathbf{2 0 0 5}$ & $\mathbf{2 0 0 8}$ \\
\hline President & 73.4 & 45.7 \\
\hline Ruling party & 58.0 & 33.9 \\
\hline National Assembly & 56.1 & 36.1 \\
\hline Opposition parties & 47.2 & 40.0 \\
\hline
\end{tabular}


Table 1 shows the levels of trust that Senegalese Afrobarometer respondents in Rounds 2 and 3 (2005 and 2008) placed in various institutions. ${ }^{7}$

As these results show, about three-quarters of the Senegalese population trusted Wade in 2005. He was far more popular than his own party or the National Assembly. This trust declined sharply in 2008, but it is noteworthy that Wade was still more trusted than the opposition. What these figures also suggest is that the linkage crisis grew between the survey years. The low level of confidence in the ruling party and the opposition alike in 2008 coincides with a remarkable drop in satisfaction with democracy: whereas in $2005,53.3 \%$ were very or fairly satisfied with the state of democracy in the country, only $26.9 \%$ reported satisfaction in 2008. This indicates that broken party-voter linkage poses a threat not only to the survival of the party in question but also to democracy as a whole.

\section{DISCUSSION: CONTINUITY AND CHANGE}

Many authors have stressed the continuity of hegemonic strategy from Senghor to Diouf and finally to Wade (Dahou \& Foucher 2009; Ottaway 2003, p 92). However, the process of adaptation and change should not be overlooked. Senghor, adept in the art of reciprocal elite assimilation (Foucher 2007b, p 188), was certainly charismatic but in terms of his linkage strategies there was an equilibrium between charisma and clientelism. Even though the introduction of multipartism limité rested on ideological premises, party programmes never played a significant role. Quite the contrary, the artificiality and inflexibility of the labels that were attached to the registered parties effectively discouraged programmatic linkage.

Senghor's successor, Diouf, lacked charisma and thus relied more strongly on clientelism, but also on the manipulation of the political process. During his term in office Senegal experienced a serious linkage crisis, with changes taking place on three levels: in the relationship between voters and the PS, in the taalibemarabout relationship and (partly as a consequence) in the relationship between religion and the state. In the 1980s a growing number of young voters could no longer be integrated into the clientelistic networks of the PS (Foucher 2007a, p 126). The economic crisis also weakened the patronage link between the PS and the Sufi brotherhoods, which began to distance themselves from the state. At the same time, a process of modernisation was underway within the brotherhoods, which altered the relationship between the marabout and the taalibe, especially in urban settings. These changes became evident in the unprecedented protests that followed the 1988 ndigel and in the khalif's silence in subsequent elections.

7 Afrobarometer question 55 reads, 'How much do you trust the following institutions?' The table displays the combined response levels for the answers 'a lot' and 'somewhat'. 
These multifaceted social transformations challenge traditional modes of linkage; they can also create circumstances that are particularly susceptible to the emergence of charismatic linkage. What Villalón (1995, p 345) has noted with regard to the charismatic authority of the marabouts applies to the political situation as well:

Two elements are generally recognized as central to the emergence of charismatic movements: (1) the quality of the message which is offered as an alternative to the old order [...], and (2) the social context of the movement in terms of the 'ripeness' of the historical moment, most frequently understood as a perceived popular need for change.

The ripeness of the moment was clearly indicated by the linkage crisis developing in the PS regime. The process was not always unambiguous and suffered some defeats along the way, for example, Wade lost some credibility because of his participation in the government in 1991 and 1995. Despite this, the PDS remained the only feasible alternative and Wade the only politician who could embody 'the new'. Using the 'blue marches', he deliberately distanced himself from the political style of the PS. The quality of his message took the simplest and most all-encompassing form possible: sopi - change. In this sense, Wade's charismatic personality and the fatigue with the PS were sides of the same coin: a situation featuring a fault line running between the 'old' and the 'new'.

Once in power Wade tried to rebuild the hegemonic alliances of his predecessors, but he did this at a time when it was already obvious that good relationships with the Sufi brotherhoods were no longer a guarantee of electoral success. The personalisation of politics was thus an attempt to adapt linkage strategies to a changing social environment. For a brief period charisma filled the void that had been left by the erosion of traditional party-voter linkage in Senegal. However, clientelistic linkage never ceased to exist and Wade won the 2007 presidential elections through a successful combination of the two.

It must be said, however, that Wade's victory against a hopelessly divided opposition was not a true test of his popular support. The emergence of Idrissa Seck as the second-place candidate indicates that within the PDS the equilibrium between charisma and clientelism was becoming unbalanced.

Wade's style of rule fits Weber's notion of charisma well: it was erratic, not bound to formal rules and was hostile to intra-party leadership competition. The politician's statement quoted above that all party functionaries other than Wade were nothing but 'variables' (Ba interview 2006) illustrates this point quite well. However, the elimination of threatening variables from the party - a strategy intended to stabilise Wade's personal rule - was precisely what put the 'Wade 
system' on the path to self-destruction. With the departure of Seck and Sall (and many others) the already fragile electoral base of the PDS was further weakened. The years after 2007 saw a rapid erosion of charisma. When the campaign slogan, sopi, began to lose momentum, the party seemed unable to replace it with an alternative appeal. It simply had no coherent social project to offer and almost no effort was made to professionalise the party organisation. Thus, the only way forward was the routinisation of charisma in the form of hereditary succession. When this attempt failed, the end of the Wade era was nigh.

In retrospect, both the PS and the PDS were stymied by a linkage crisis to which neither could find a solution. Although the PDS was the party most affected there are indications that the linkage crisis was more generalised. As the results of the Afrobarometer survey of 2008 (shown in Table 1) demonstrate, neither the ruling party nor the opposition enjoyed the trust of even half the population. The opposition, particularly Macky Sall, benefited from the broken link between the PDS and the electorate. This must, of course, be seen in the wider context of the economic and social situation of the country, which is characterised by recurring power failures, commodity price hikes and growing social inequality.

Despite these hardships the Senegalese people appear to be deeply committed to democracy as the preferred form of governance. The desire for more accountable political leaders, better governance and respect for the Constitution was clearly expressed by the opposition movement M23. Against this backdrop, the current administration will have to build its own stable relationship with the populace. Sall is not overly charismatic and a return to the near-perfect Senghor model of reciprocal elite assimilation is highly unlikely.

Two scenarios are possible: on the one hand, there is a growing regionalisation of politics, evidenced by the support for Sall in Fatick, Seck in Thiès, and Niasse in Kaolack. This tendency towards regionalisation, already noted by Beck (2008, p 227) could make patronage distribution more predictable and thereby help parties to build more clearly defined constituencies that could be bound by clientelistic linkage. The flip side of this tendency is that it may lead to a politicisation of identities thus far largely unknown in Senegal, with a negative impact on Senegalese society as a whole. The other possibility would be that parties could start to compete over issues and programmes. As the low turnout in the 2012 parliamentary elections shows, the rebuilding of party-voter linkages is vital for the country's democratic future. 


\section{- REFERENCES}

\section{Publications}

Abrahamsen, R. 2000. Disciplining Democracy: Development Discourse and Good Governance in Africa. London: Zed Books.

Ake, C. 2000. The Feasibility of Democracy in Africa. Dakar: Council for the Development of Social Science Research in Africa.

Audrain, X. 2004. 'Du “Ndigël' avorté" au Parti de la vérité'. Politique Africaine 96. Bayart, J-F. 1993. The State in Africa: The Politics of the Belly. London: Longman.

Beck, L J. 2008. Brokering Democracy in Africa: The Rise of Clientelist Democracy in Senegal. New York: Palgrave Macmillan.

Bleck, J \& N van de Walle. 2011. 'Parties and issues in Francophone West Africa: Towards a theory of non-mobilization'. Democratization 18(5).

Bratton, M \& N van de Walle. 1997. Democratic Experiments in Africa: Regime Transitions in Comparative Perspective. Cambridge: Cambridge University Press.

Chabal, P \& J-P Daloz. 1999. Africa Works: Disorder as Political Instrument. London: James Currey.

Cheeseman, N \& M Hinfelaar. 2009. 'Parties, platforms, and political mobilization: The Zambian presidential election of 2008'. African Affairs 109(434).

Clapham, C. 1982. Private Patronage and Public Power: Political Clientelism in the Modern State. London: Frances Pinter.

Copans, J. 1980 Les Marabouts de l'Arachide: la Confrérie mouride et les paysans du Sénégal. Paris: Le Sycomore.

Copans, J. 2000. 'Mourides des champs, mourides des villes, mourides du téléphone portable et de l'internet: les renouvellements de l'économie politique d'une confrérie'. Afrique Contemporaine 194(2).

Coulon, C. 1981. Le Marabout et le Prince: Islam et pouvoir au Sénégal. Paris: Pedone.

Creevey, L, P Ngomo \& R Vengroff. 2005. ‘Party politics and different paths to democratic transitions'. Party Politics 11(4).

Cruise O'Brien, D B. 1998. 'The shadow-politics of Wolofisation'. The Journal of Modern African Studies 36(1).

Cruise O'Brien, D B. 2003. Symbolic Confrontations: Muslims Imagining the State in Africa. New York: Hurst and Co.

Dahou, T \& V Foucher. 2009. 'Senegal since 2000: Rebuilding hegemony in a global age'. In A Raufu \& L Whitfield (eds). Turning Points in African Democracy. Woodbridge and Rochester: Boydell and Brewer.

De Jong, F \& V Foucher. 2010. ‘La tragédie du roi Aboulaye? Néomodernisme et renaissance africaine dans le Sénégal contemporain'. Politique Africaine 118.

Desouches, C. 1983. Le Parti Démocratique sénégalais. Paris: Berger-Levrault.

Diaw, A \& M Diouf. 1998. 'The Senegalese opposition and its quest for power'. In A Olukoshi (ed). The Politics of Opposition in Contemporary Africa. Uppsala: Nordiska Afrikainstitutet. 
Diouf, M.1996. 'Urban youth and Senegalese politics: Dakar 1988-1994'. Public Culture 8(2).

Erdmann, G. 2004. 'Party research: Western European bias and the "African labyrinth"'. Democratization 11.

Fatton, R. 1987. The Making of a Liberal Democracy: Senegal's Passive Revolution, 1975-1985. Boulder: Lynne Rienner Publishers.

Foucher, V. 2007a. 'Blue marches in Senegal'. In J C Strauss \& D B Cruise O'Brien (eds). Staging Politics: Power and Performance in Asia and Africa. London: Tauris.

Foucher, V. 2007b. 'Senegal: the resilient weakness of Casamancais separatists'. In M.Bøås \& K C Dunn (eds). African Guerrillas: Raging Against the Machine. Boulder: Lynne Rienner Publishers.

Gellar, S. 2005. Democracy in Senegal: Tocquevillian Analytics in Africa. New York: Palgrave Macmillan.

Gordin, J P. 2002. 'The political and partisan determinants of patronage in Latin America 1960-1994: A comparative perspective'. European Journal of Political Research 41(4).

Havard, J-F. 2004. 'De la victoire du "sopi" à la tentation du "nopi"? Gouvernement de l'alternance et liberté d'expression des médias au Sénégal'. Politique Africaine 96.

Hawkins, K. 2003. 'Populism in Venezuela: The rise of Chavismo'. Third World Quarterly 24(6).

Hicken, A. 2011. 'Clientelism'. Annual Review of Political Science 14.

Jackson, R \& C G Rosberg. 1982. Personal Rule in Black Africa: Prince, Autocrat, Prophet, Tyrant. Berkeley: University of California Press.

Keefer, P. 2005. 'Clientelism, credibility and the policy choices of young democracies'. Washington, DC: The World Bank Development Research Group.

Key, V O. 1961. Public Opinion and American Democracy. New York: Knopf.

Kitschelt, H. 2000. 'Linkages between citizens and politicians in democratic polities'. Comparative Political Studies 33(6-7).

Kitschelt, H, K Freeze, K Kolev \& Y-T Wang. 2009. 'Measuring democratic accountability: An initial report on an emerging data set'. Revista de Ciencia Política 29(3).

Lawson, K.1980. Political Parties and Linkage: A Comparative Perspective. New Haven: Yale University Press.

Lawson, K.1988. 'When linkage fails'. In K. Lawson and P. H. Merkl (eds).When Parties Fail: Emerging Alternative Organizations. New Jersey: Princeton University Press.

Lemarchand, R \& K Legg. 1972. 'Political clientelism and development: A preliminary analysis'. Comparative Politics 4(2).

Lindberg, S I \& MKC Morrison. 2008. 'Are African voters really ethnic or clientelistic? Survey evidence from Ghana'. Political Science Quarterly 123(1). 
Leonard, D K \& S Straus. 2003. Africa's Stalled Development: International Causes and Cures. Boulder: Lynne Rienner Publishers.

Lipset, S M \& S Rokkan. 1967. Party Systems and Voter Alignments: Cross-national Perspectives. New York: Free Press.

Mainwaring, S \& M Torcal. 2006. 'Party system institutionalization and party system theory after the Third Wave of Democratization'. In R S Katz \& W J Crotty (eds). Handbook of Party Politics 11(6).

Mbow, P. 2008. 'Senegal: The Return of Personalism'. Journal of Democracy 19(1).

Mkandawire, T. 1999. 'Crisis management and the making of "choiceless democracies" in Africa'. In R A Joseph (ed). State, Conflict, and Democracy in Africa. Boulder: Lynne RiennerPublishers.

Moegenburg, I. 2002. Die Parteienlandschaft im Senegal: tragfähige Grundlage der Demokratisierung? Münster: LIT Verlag.

Morgan, J. 2011. Bankrupt Representation and Party System Collapse. University Park: Penn State Press.

Osei, A. 2012. Party-Voter Linkage in Ghana and Senegal: A Comparative Perspective. Wiesbaden: VS Verlag.

Ottaway, M. 2003. Democracy Challenged: The Rise of Semi-authoritarianism. Washington, DC: Carnegie Endowment.

Parti Démocratique Sénégalais (PDS). nd. Statuts du Parti Démocratique Sénégalais.

Posner, D N. 2005. Institutions and Ethnic Politics in Africa. Cambridge: Cambridge University Press.

Römmele, A, D M Farrell \& P Ignazi. 2005. ‘The prevalence of linkage by reward in contemporary parties'. In A Römmele, D M Farrell \& P Ignazi (eds). Political Parties and Political Systems: The Concept of Linkage Revisited. London: Praeger.

Sadji, A B. 2006. Le Rôle de la Génération Charnière Ouest-Africaine: Indépendance et Développement. Paris: L'Harmattan.

Sartori, G. 2005 [1976]. Parties and Party Systems: A Framework for Analysis. Colchester: ECPR Press.

Schatzberg, M G. 2001. Political Legitimacy in Middle Africa: Father, Family, Food. Bloomington, IN: Indiana University Press.

Villalón, L A. 1995. Islamic Society and State Power in Senegal: Disciples and Citizens in Fatick. Cambridge: Cambridge University Press.

Villalón, L A. 1999. 'Generational change, political stagnation, and the evolving dynamics of religion and politics in Senegal'. Africa Today 46(3/4).

Villalón, L A \& O Kane. 1998. 'Senegal: the crisis of democracy and the emergence of an Islamic opposition'. In L A Villalón \& P A Huxtable (eds). The African State at a Critical Juncture: Between Disintegration and Reconfiguration. Boulder: Lynne Rienner Publishers.

Van de Walle, N. 2003. 'Presidentialism and clientelism in Africa's emerging party systems'. Journal of Modern African Studies 41(2).

Weber, M. 1978. Economy and Society: An Outline of Interpretive Sociology. Berkley: University of California Press. 
Wiseman, J A. 1998. The New Struggle for Democracy in Africa. Aldershot: Ashgate.

Young, C. 1999. 'The Third Wave of Democratization in Africa: ambiguities and contradictions'. In R A Joseph (ed). State, Conflict and Democracy in Africa. Boulder: Lynne Rienner Publishers.

Young, D J. 2009. 'Is clientelism at work in African elections?' Afrobarometer Working Paper No 106. Accra: Afrobarometer.

\section{Interviews}

Ba, Lamine, Secrétaire Administratif Adjoint, PDS, Dakar, 30 October 2006.

DibiDiallo, Mamadou, SecrétaireGénéral de Bakel, PDS, Dakar, 8 December 2007.

Faye, Lea Christine, deputy mayor of Thiès and local women's organiser, Rewmi, Thiès, 6 December 2007.

Sy Diallo, Mata, Premier Secrétaire Adjoint de la Délégation Communale de Kaolack, AFP, Dakar, 12 December 2007.

Fall, Bakhao, Secrétaire de la Coordination Départementale de Mbacké, PS, Mbacké, 10 December 2007.

Kane, Falilou, Secrétaire Général de la Délégation de Mbacké, AFP, Mbacké, 10 December 2007.

Thiare, Dib, Secrétaire Perma National, PDS, Dakar, 26 November 2007. 